\title{
A neutralization-inhibition enzyme immunoassay for anti-idiotypic antibodies that block monoclonal antibodies neutralizing Semliki Forest virus
}

\author{
T.A.M. Oosterlaken, M. Harmsen, C. Tangerman, P. Schielen, C.A. Kraaijeveld and H. Snippe \\ Laboratory of Microbiology, University of Utrecht, Catharijnesingel 59, 3511 GG Utrecht, The Netherlands
}

(Received 25 April 1988, revised received 21 July 1988, accepted 23 July 1988)

In this paper we compare a solid-phase enzyme immunoassay (EIA) with a neutralization-inhibition enzyme immunoassay (NI-EIA) for the determination of anti-idiotypic antibodies against Semliki Forest virus (SFV)-neutralizing monoclonal antibodies (MAs) UM 5.1 (IgG2a) and UM 1.4 (IgG2a). Against these MAs strong immune sera were induced in female BALB/c mice by two subcutaneous injections, 3 weeks apart, with keyhole limpet hemocyanin coupled MA mixed with the saponin Quil A. Rabbit immune sera were prepared by intracutaneous injections of purified MA mixed with either FCA (first immunization) or IFA (second and third immunization). In the NI-EIA serum is preincubated with neutralizing MA, in wells of 96-well plates, before SFV is added. Binding of anti-idiotypic antibodies to MA results in a diminished capacity of that MA to neutralize SFV. After $1 \mathrm{~h}$ incubation with SFV L cells are added and residual infectious virus is allowed to multiply for $6 \mathrm{~h}$ at $37^{\circ} \mathrm{C}$. Then the monolayers are fixed with glutaraldehyde and subsequently SFV is quantified with a horseradish peroxidase-labelled SFV-specific MA. Low absorbance values indicate that the neutralizing capacity of MA is intact and that blocking antibodies were not present in serum. In contrast high absorbance values indicate that blocking (anti-idiotypic) antibodies had abrogated the neutralizing capacity of MA. With the strongly neutralizing MA UM 5.1 as idiotypic antigen the NI-EIA proved to be at least as sensitive as the solid-phase EIA. Furthermore both normal mouse serum-absorbed rabbit immune sera and mouse immune sera were not cross-reactive in both solid-phase EIA and NI-EIA.

Key words: Anti-idiotypic antibody; Semliki Forest virus; Monoclonal antibody, neutralizing; Enzyme immunoassay

\section{Introduction}

At present there is a growing interest in the development of anti-idiotypic vaccines against virus diseases (Kennedy and Dreesman, 1985; Uytdehaag and Osterhaus, 1985; Burdette and

Correspondence to: T.A.M. Oosterlaken, Laboratory of Microbiology, University of Utrecht, Catharijnesingel 59, 3511 GG Utrecht, The Netherlands.
Schwartz, 1987; Köhler et al., 1985). Therefore convenient tests for detection of anti-idiotypic antibodies (candidate vaccines) against virus-neutralizing monoclonal antibodies (MAs) are of special interest. Most methods used are solid-phase enzyme immunoassays (EIAs), which measure binding or inhibition of either enzyme- or isotopelabelled MAs to corresponding anti-idiotypic antibodies in immune sera. Previously, we described an EIA on cell cultures for the rapid titration of Semliki Forest virus (SFV)-neutralizing antibodies 
in serum (Van Tiel et al., 1986). In the present study this EIA proved to be very useful for the determination of anti-idiotypic antibodies that abrogate specifically the virus neutralizing capacity of SFV-neutralizing antibodies. The test is based on inhibition of the neutralizing capacity of SFV-specific MAs by preincubation with anti-idiotypic serum.

\section{Materials and methods}

\section{Semliki Forest virus}

The prototype strain of SFV was used (Boere et al., 1986). The virus was passed once over $L$ cells and had a titre of $10^{9}$ plaque-forming units (p.f.u.) $/ \mathrm{ml}$. SFV was stored in small portions at $-70^{\circ} \mathrm{C}$. General virological methods as plaque titration have been described previously (Boere et al., 1984).

\section{Cells and media}

L cells, a continuous line of mouse fibroblasts, were maintained in Dulbecco's minimal essential

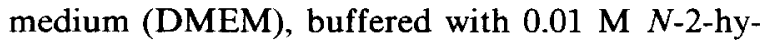
droxyethyl-piperazine- $N^{\prime}$-ethane sulfonic acid (Hepes), supplemented with $5 \%$ calf serum, $0.2 \%$ tryptose (Difco Laboratories, Detroit, MI) and antibiotics.

\section{Monoclonal antibodies}

In the present study we used two SFV-neutralizing MAs: UM 1.4 and UM 5.1, with 50\% plaque reduction titers $\left(\mathrm{PRT}_{50}\right)$ of respectively $5 \times 10^{4}$ and $10^{6}$. Both MAs are of the IgG2a immunoglobulin subclass, specific for the $\mathrm{E}_{2}$ glycoprotein of SFV and non-competitive (Boere et al., 1984; our own unpublished results).

The production, purification and biological characterization of SFV-specific MAs have been described earlier (Boere et al., 1984). The MAs were obtained after fusion of spleen cells from immunized BALB/c mice with the myeloma line P3-X63-AG.8.653 (Fazekas de St.Groth and Scheidegger, 1980).

\section{Enzyme-labelling of $M A$}

Horseradish peroxidase (HRPO) was conjugated to MA-containing ascitic fluids by the periodate method (Nakane and Kawaoi, 1974). The conjugates were stored at $4^{\circ} \mathrm{C}$. Immediately before use the conjugates were diluted in phosphate-buffered saline (PBS) with $0.05 \%$ Tween 20 . End dilutions varied between 1/20000 and $1 / 50000$.

\section{Coupling of MA to keyhole limpet hemocyanin}

Protein A-Sepharose-purified MA (Ey et al., 1978) was coupled chemically to keyhole limpet hemocyanin (KLH). In brief: $0.8 \mathrm{mg}$ purified MA in $0.1 \mathrm{ml}$ PBS ( $\mathrm{pH} \mathrm{7.2)} \mathrm{was} \mathrm{mixed} \mathrm{with} 1 \mathrm{mg}$ (in $0.2 \mathrm{ml} \mathrm{PBS}$ ) of $\mathrm{KLH}$ and then coupled to each other by the addition of $0.06 \mathrm{ml} 2.5 \%$ glutaraldehyde. After $5 \mathrm{~min}$ incubation at room temperature the reaction was stopped with $0.06 \mathrm{ml}$ of $0.2 \mathrm{M}$ glycine. After addition of $0.58 \mathrm{ml}$ aq. dest., the antigen was dialyzed overnight at $4{ }^{\circ} \mathrm{C}$ against aq. dest. The dialyzed conjugates were used to immunize female BALB/c mice.

\section{Immunization of mice}

Dialyzed conjugates of KLH and MAs UM 5.1 and UM $1.4(1 \mathrm{ml}$ each conjugate) were mixed with $1 \mathrm{ml}(0.4 \mathrm{mg})$ of the adjuvant Quil A (Sigma Chemicals, St. Louis, MO). 12-week-old female BALB/c mice, bred and kept in our own animal house, were injected intra/subcutaneously with $0.1 \mathrm{ml}$ of the adjuvant-antigen mixture (equivalent to $40 \mu \mathrm{g}$ of purified MA). At various intervals after primary immunization, before and after booster injection (generally at day 21) blood was obtained from ether-anesthetized mice by retroorbital puncture. The individual sera were tested for the presence of anti-idiotypic antibodies.

\section{Immunization of rabbits}

To induce anti-idiotypic antibodies rabbits were injected with protein A-Sepharose-purified MAs UM 5.1 (IgG2a) and UM 1.4 (IgG2a). At the time of primary immunization the two rabbits, first generation off-spring of New Zealand rabbits and Flemish giant rabbits, were 1 year old and weighed $4.5 \mathrm{~kg}$. The following immunization schedule was used: at day 0 , intracutaneous injection of a mixture of $1.5 \mathrm{mg} \mathrm{MA}$ in $0.75 \mathrm{ml}$ PBS and $0.75 \mathrm{ml}$ Freund complete adjuvant (FCA) at 15 different sites $(15 \times 0.1 \mathrm{ml})$ of the back skin; at day 34 and day $811.5 \mathrm{mg}$ MA and incomplete Freund ad- 
juvant (IFA) was injected similarly. Serum was obtained at days $0,28,47$ and 95 of immunization. In this study we used immune serum obtained at day 95 . As control serum served normal rabbit serum (NRS). The immune sera were absorbed with normal mouse serum (NMS) to remove allotypic and isotypic antibodies. One part of either undiluted rabbit immune serum or NRS was mixed with four parts of NMS and incubated overnight at $4^{\circ} \mathrm{C}$ before use.

Solid-phase enzyme immunoassay for determination of anti-idiotypic antibodies

In the EIA wells of 96-well plates (cat. no. 3596, Costar Plastics, Cambridge, MA) were coated overnight at $4^{\circ} \mathrm{C}$ with $0.2 \mu \mathrm{g}$ of purified $\mathrm{MA}$ in $0.1 \mathrm{ml}$ carbonate buffer of $\mathrm{pH}$ 9.6. After coating the buffer fluid was discarded and $0.1 \mathrm{ml}$ PBSG (PBS + 0.5\% gelatine), prewarmed to $37^{\circ} \mathrm{C}$, was added to each well and incubated for $30 \mathrm{~min}$. Next the plates were washed consecutively with PBST (PBS + 0.5\% Tween), tap water and PBS alone. Subsequently $0.1 \mathrm{ml}$ aliquots of either mouse or rabbit anti-idiotypic serum, diluted in PBST, supplemented with $3.5 \%$ bovine serum albumin (BSA), were added to the wells and incubated for $1 \mathrm{~h}$ at $37^{\circ} \mathrm{C}$ followed by careful rinsing of the wells with tap water. Thereafter $0.1 \mathrm{ml}$ portions of HRPO-labelled MA were added and incubated for $1 \mathrm{~h}$ at $37^{\circ} \mathrm{C}$. The amount of bound peroxidase was visualized by incubation with $0.1 \mathrm{ml}$ of a solution of 3,3',5,5'-tetramethylbenzidine (Sigma Chemical Co.) and urea peroxide (Organon Teknika, Boxtel, The Netherlands). After $30 \mathrm{~min}$ of incubation at room temperature, the enzyme reaction was stopped with $0.1 \mathrm{ml}$ of $0.18 \mathrm{M}$ $\mathrm{H}_{2} \mathrm{SO}_{4} /$ well and the reaction was quantified by measuring the optical density at $450 \mathrm{~nm}$ with a Titertek Multiscan photometer (Flow Laboratories, Irvine, Scotland, U.K.).

Determination of the neutralizing capacities of MAs by enzyme immunoassay

MA-containing ascitic fluids were serially diluted in DMEM, supplemented with 5\% calf serum, in wells of 96 well plates. To the dilutions of MA $(0.025 \mathrm{ml})$ a standard dose of 200000 p.f.u. of the prototype strain of SFV in $0.025 \mathrm{ml}$ complete medium was added and thereafter mixed. The
virus/MA mixtures were incubated for $1 \mathrm{~h}$ at $37^{\circ} \mathrm{C}$ before $20000 \mathrm{~L}$ cells $(0.1 \mathrm{ml})$ were seeded into each well to form monolayers. After a multiplication period of $6 \mathrm{~h}$ at $37^{\circ} \mathrm{C}$ the monolayers were fixed with $0.05 \%$ glutaraldehyde and then washed with tap water and rinsed with PBS of $\mathrm{pH}$ 7.2. After washing and rinsing with PBS the EIA was performed with a SFV-specific MA-HRPO conjugate as described in the preceding paragraph.

\section{EIA for determination of anti-idiotypic antibodies}

Anti-idiotypic antibodies present in either rabbit serum or mouse serum were titrated with a neutralization inhibition enzyme immunoassay (NI-EIA). Volumes of $0.025 \mathrm{ml}$ of either diluted MA UM 1.4 or MA UM 5.1 (ascitic fluids) were mixed with serially diluted anti-idiotypic sera $(0.025 \mathrm{ml})$ in wells of 96 -well plates. Normal rabbit serum (NRS) or normal mouse serum (NMS) were used as negative control sera. After $1 \mathrm{~h}$ incubation at $37^{\circ} \mathrm{C}, 200000$ p.f.u. $(0.025 \mathrm{ml})$ of $\mathrm{SFV}$ was added to these MA-serum mixtures and the incubation was continued for another $1 \mathrm{~h}$ at $37^{\circ} \mathrm{C}$. Then to each well $20000 \mathrm{~L}$ cells $(0.1 \mathrm{ml})$ were seeded to form monolayers. Non-neutralized SFV was allowed to multiply for $6 \mathrm{~h}$ at $37^{\circ} \mathrm{C}$ before the EIA was performed with a HRPOlabelled SFV-specific MA as described in a preceding paragraph. The titer of anti-idiotypic serum could be defined arbitrarily as that dilution causing $50 \%$ inhibition of the control absorbance value.

\section{Results}

Detection of specific idiotypes on MAs UM 5.1 and UM 1.4 with solid-phase EIA

The antisera prepared in both rabbits and mice against purified MAs UM 5.1 (IgG2a) and UM 1.4 (IgG2a) were titrated on their content of antiidiotypic antibodies with the solid-phase EIA. The sera were added in two step dilutions to wells coated with either purified MA UM 5.1 or purified MA UM 1.4. After incubation with serum either HRPO-labelled MA UM 5.1 or HRPOlabelled MA UM 1.4 was added to the wells. Subsequently bound enzyme was demonstrated by the color reaction of substrate. The mean absorbance values at each dilution of NMS-absorbed 
TABLE I

DETECTION WITH SOLID-PHASE EIA OF SPECIFIC IDIOTYPES ON TWO SFV NEUTRALIZING MAS WITH NMS ABSORBED RABBIT ANTISERA AGAINST THESE MAS

\begin{tabular}{|c|c|c|c|c|c|c|c|c|c|c|}
\hline \multirow{2}{*}{$\begin{array}{l}\text { Anti- } \\
\text { gen: } \\
\text { purified } \\
\text { MA }^{\mathbf{a}}\end{array}$} & \multirow{2}{*}{$\begin{array}{l}\text { Rabbit } \\
\text { antiserum } \\
\text { against } \\
\text { MA }\end{array}$} & \multirow{2}{*}{$\begin{array}{l}\text { HRPO- } \\
\text { conju- } \\
\text { gated } \\
\text { MA }^{b}\end{array}$} & \multicolumn{8}{|c|}{ Mean $(n=2)$ absorbance values at serial antiserum dilutions $(\times 1000)$} \\
\hline & & & $1 / 2$ & 1 & 2 & 4 & 8 & 16 & 32 & 64 \\
\hline 5.1 & 1.4 & 5.1 & 0.066 & 0.063 & 0.057 & 0.060 & 0.054 & 0.056 & 0.054 & 0.056 \\
\hline 5.1 & 5.1 & 5.1 & 1.000 & 1.017 & 0.861 & 0.691 & 0.426 & 0.241 & 0.158 & 0.106 \\
\hline 1.4 & 5.1 & 1.4 & 0.069 & 0.064 & 0.058 & 0.063 & 0.053 & 0.060 & 0.066 & 0.109 \\
\hline 1.4 & 1.4 & 1.4 & 1.041 & 0.940 & 0.919 & 0.925 & 0.832 & 0.792 & 0.500 & 0.296 \\
\hline
\end{tabular}

${ }^{\text {a }} 0.2 \mu \mathrm{g} /$ well.

b Conjugates diluted $1 / 32000$.

rabbit immune sera are given in Table I. Both absorbed antisera bind specifically to unlabelled and labelled MA. The titers of the absorbed rabbit immune sera antisera are about 1/16000 (anti-UM 5.1) and 1/64000 (anti-UM 1.4).

The mean absorbance values obtained with mouse anti-idiotypic sera against MAs UM 5.1 and UM 1.4 are given in Table II. Both mouse immune sera contain high levels of antibodies against their homologous antigen. The reactions observed after reaction with heterologous antigens are comparable to those measured after incubation with NMS. The results indicate that both NMS-absorbed rabbit immune sera and mouse immune sera against MAs UM 5.1 and UM 1.4 contain specific anti-idiotypic antibodies.

Determination of the neutralizing capacities of MAs UM 1.4 and $U M 5.1$ by EIA

MA UM 1.4 or MA UM 5.1 were serially diluted $\left(-{ }^{10} \log\right.$ dilutions: $2.5,3.0,3.5,4.0,4.5$, $5.0,5.5,6.0,6.5$ and 7.0 ) in wells of 96-well plates. The dilutions of MA were mixed with standard infectious doses $\left(2 \times 10^{5}\right.$ p.f.u.) of SFV and incubated for $1 \mathrm{~h}$ at $37^{\circ} \mathrm{C}$ before $20000 \mathrm{~L}$ cells were seeded into each well to form monolayers. After 6 $\mathrm{h}$ incubation at $37^{\circ} \mathrm{C}$ SFV-infected cells were detected with either HRPO-labelled MA UM 1.4 or HRPO-labelled MA UM 5.1. As shown in Fig. 1 neutralization of SFV by MA is indicated by inhibition of absorbance. MA UM 1.4 neutralized SFV to a dilution over 5.0 and MA UM 5.1 to a dilution over 6.5 . The results also indicate that
UM 5.1 and UM 1.4, conjugated to HRPO, are equally useful in the EIA.

Detection of anti-idiotypic antibodies with the neutralization inhibition EIA

Preincubation of a neutralizing dose of MA

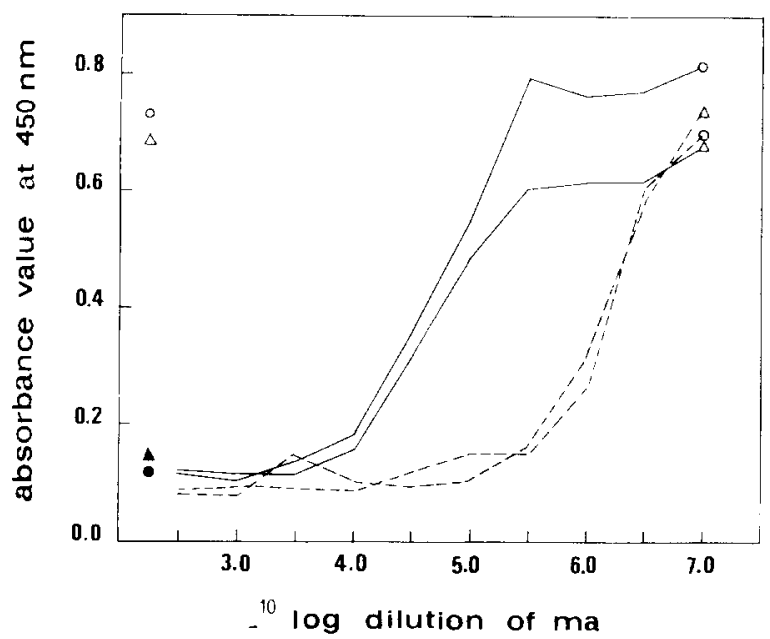

Fig. 1. Determination of the neutralizing capacity of MAs by EIA. Dilutions of MAs UM 5.1 and UM 1.4 were mixed with SFV and incubated for $1 \mathrm{~h}$ at $37^{\circ} \mathrm{C}$ in 96-well plates before $\mathrm{L}$ cells were seeded into the wells to form monolayers (resulting MOI: 10). After $6 \mathrm{~h}$ of incubation at $37^{\circ} \mathrm{C}$ the EIA was performed with both HRPO-labelled MA UM 5.1 (O) and HRPO-labeled MA UM $1.4(\Delta)$. The continuous lines represent the neutralization curves of unlabelled MA UM 1.4 and the broken lines those of unlabelled MA UM 5.1. The points plotted are values for single measurements. Mean absorbance values measured against noninfected $\mathrm{L}$ cells $(\bullet, \Delta, n=4)$ and against control infected $L$ cells $(O, \Delta, n=12)$ are presented as single symbols. 
TABLE II

DETECTION WITH SOLID-PHASE EIA OF SPECIFIC IDIOTYPES ON SFV NEUTRALIZING MAs UM 5.1 (IgG2a) AND UM 1.4 (IgG2a) USING MOUSE ANTISERA AGAINST THESE MAs

\begin{tabular}{|c|c|c|c|c|c|c|c|c|c|}
\hline \multirow{2}{*}{$\begin{array}{l}\text { Anti- } \\
\text { gen: } \\
\text { purified } \\
\text { MA }^{\mathbf{a}}\end{array}$} & \multirow{2}{*}{$\begin{array}{l}\text { Mouse } \\
\text { antiserum } \\
\text { against } \\
\text { MA }^{\text {b }}\end{array}$} & \multirow{2}{*}{$\begin{array}{l}\text { HRPO- } \\
\text { labelled } \\
\text { MA }^{\mathbf{c}}\end{array}$} & \multicolumn{7}{|c|}{ Mean $(n=2)$ absorbance values at reciprocal antiserum dilution } \\
\hline & & & $\overline{40}$ & 80 & 160 & 320 & 640 & 1280 & 2560 \\
\hline 5.1 & NMS & 5.1 & 0.052 & 0.053 & 0.043 & 0.050 & 0.043 & 0.034 & 0.036 \\
\hline 5.1 & 1.4 & 5.1 & 0.047 & 0.051 & 0.035 & 0.038 & 0.035 & 0.029 & 0.026 \\
\hline 5.1 & 5.1 & 5.1 & 0.593 & 0.446 & 0.520 & 0.458 & 0.345 & 0.234 & 0.100 \\
\hline 1.4 & NMS & 1.4 & 0.352 & 0.300 & 0.235 & 0.126 & 0.062 & 0.031 & 0.034 \\
\hline 1.4 & 5.1 & 1.4 & 0.415 & 0.331 & 0.242 & 0.158 & 0.085 & 0.041 & 0.035 \\
\hline 1.4 & 1.4 & 1.4 & 1.006 & 0.946 & 0.782 & 0.690 & 0.588 & 0.411 & 0.227 \\
\hline
\end{tabular}

a $0.2 \mu \mathrm{g}$ /well.

b Mice were immunized i.c. at day 0 and day 21 with KLH coupled MA and Quil A. Blood was obtained at day 28.

c Conjugates diluted to $1 / 64000$ (UM 1.4) and 1/128000 (UM 5.1).

with anti-idiotypic serum leads to a diminished capacity of that MA to neutralize. This is demonstrated in the next experiment with the neutralization inhibition (NI-) EIA. Nonabsorbed and NMS-absorbed rabbit anti-UM 1.4, anti-UM 5.1, and NRS were serially diluted $\left(-{ }^{10} \log\right.$ dilutions: 2.0, 2.5, 3.0, 3.5, 4.0, 4.5 and 5.0) and each dilution was mixed with a dilution $\left(-{ }^{10} \log : 3.0,3.5,4.0\right.$, $4.5,5.0,5.5$ and 6.0 ) of either MA UM 1.4 or MA
UM 5.1 (IgG2a). The MA serum mixtures were incubated overnight at $4^{\circ} \mathrm{C}$ before addition of 200000 p.f.u. of SFV to each well. After $1 \mathrm{~h}$ incubation at $37^{\circ} \mathrm{C} \mathrm{L}$ cells were added and nonneutralized SFV was allowed to multiply for $6 \mathrm{~h}$ at $37^{\circ} \mathrm{C}$. Subsequently the EIA was performed. Only results illuminating relevant aspects of the NI-EIA, such as cross-reactions and sensitivity, are presented (Table III, Fig. 2). Table III shows that

TABLE III

DETECTION WITH NI-EIA OF SPECIFIC ANTI-IDIOTYPIC ANTIBODIES IN RABBIT IMMUNE SERA AGAINST SFV SPECIFIC MAs UM 5.1 (IgG2a) AND UM 1.4 (IgG2a)

\begin{tabular}{|c|c|c|c|c|c|c|c|c|c|c|}
\hline \multicolumn{2}{|c|}{$\overline{\text { Rabbit sera }}$} & \multicolumn{2}{|c|}{ Idiotypic MA } & \multirow{2}{*}{\multicolumn{7}{|c|}{$\begin{array}{l}\% \text { inhibition in NI-EIA of the neutralizing activity } \\
\text { of MA by rabbit sera at serial }-{ }^{10} \log \text { dilution }{ }^{a}\end{array}$}} \\
\hline \multirow{2}{*}{$\begin{array}{l}\text { Induced } \\
\text { against } \\
\text { purified } \\
\text { MA }\end{array}$} & \multirow{2}{*}{$\begin{array}{l}\text { Nonabsorbed }(-) \\
\text { or } \\
\text { absorbed }(+) \\
\text { with NMS }\end{array}$} & \multirow{2}{*}{$\begin{array}{l}\text { Clone } \\
\text { no. }\end{array}$} & \multirow{2}{*}{$\begin{array}{l}-{ }^{10} \log \\
\text { dilution }\end{array}$} & & & & & & & \\
\hline & & & & $\overline{2.0}$ & 2.5 & 3.0 & 3.5 & 4.0 & 4.5 & 5.0 \\
\hline NRS & - & UM 5.1 & 5.5 & 3 & 0 & 1 & -3 & -1 & 1 & 4 \\
\hline UM 5.1 & - & UM 5.1 & 5.5 & 145 & 137 & 105 & 105 & 109 & 106 & 25 \\
\hline UM 5.1 & + & UM 5.1 & 5.5 & 105 & 100 & 103 & 100 & 97 & 90 & 20 \\
\hline UM 1.4 & - & UM 5.1 & 5.5 & 103 & 75 & 84 & 71 & 5 & -7 & -7 \\
\hline UM 1.4 & + & UM 5.1 & 5.5 & 2 & 2 & -6 & 0 & 1 & 3 & -1 \\
\hline NRS & + & UM 1.4 & 4.0 & 4 & 1 & -4 & -3 & -1 & -3 & -3 \\
\hline UM 1.4 & - & UM 1.4 & 4.0 & 166 & 169 & 160 & 123 & 30 & -5 & -4 \\
\hline UM 1.4 & + & UM 1.4 & 4.0 & 87 & 108 & 53 & 3 & 5 & -5 & -4 \\
\hline UM 5.1 & - & UM 1.4 & 4.0 & 120 & 136 & 12 & -11 & -10 & -4 & -1 \\
\hline UM 5.1 & + & UM 1.4 & 4.0 & -9 & -9 & -7 & -4 & -4 & -1 & -2 \\
\hline
\end{tabular}

a $\%$ inhibition $=100 \% \times \frac{A_{450} \text { with rabbit serum }}{A_{450} \text { virus control }-A_{450} \text { idiotypic control }}$ 
TABLE IV

TITRATION OF MOUSE ANTI-IDIOTYPIC SERA AGAINST MA UM S.1 WITH NI-EIA

\begin{tabular}{|c|c|c|c|c|c|c|c|c|c|}
\hline \multicolumn{2}{|c|}{ Individual mouse sera ${ }^{a}$} & \multirow{2}{*}{\multicolumn{8}{|c|}{$\begin{array}{l}\text { inhibition of the neutralizing activity of MA UM } 5.1 \text { by serial reciprocal dilutions } \\
\text { of anti-idiotypic sera }\end{array}$}} \\
\hline \multirow{2}{*}{ no. } & \multirow{2}{*}{$\begin{array}{l}\text { Immune }(+) \\
\text { or control }(-)\end{array}$} & & & & & & & & \\
\hline & & 8 & 16 & 32 & 64 & 128 & 256 & 512 & 1024 \\
\hline 1 & - & 0 & -2 & 0 & -2 & 1 & -2 & -4 & -4 \\
\hline 2 & + & 78 & 90 & 88 & 81 & 87 & 93 & 14 & -1 \\
\hline 3 & + & 75 & 82 & 102 & 100 & 103 & 98 & 58 & 8 \\
\hline 4 & + & 83 & 86 & 93 & 98 & 97 & 101 & 61 & 7 \\
\hline 5 & + & 87 & 85 & 92 & 101 & 103 & 101 & 23 & 4 \\
\hline 6 & + & 76 & 86 & 91 & 99 & 101 & 101 & 12 & 2 \\
\hline
\end{tabular}

${ }^{a}$ Mice were immunized intra/subcutaneously with $0.1 \mathrm{ml}$ of Quil A KLH-MA UM 5.1 mixture at days 0,21 and 42 . Blood was obtained at day 52 and used in the present experiment.

b For calculation of $\%$ inhibition see legend Table III.

both anti-idiotypic immune sera can abrogate the neutralizing capacities of the corresponding MAs if appropriate antibody mixtures are used. The two nonabsorbed anti-idiotypic immune sera show

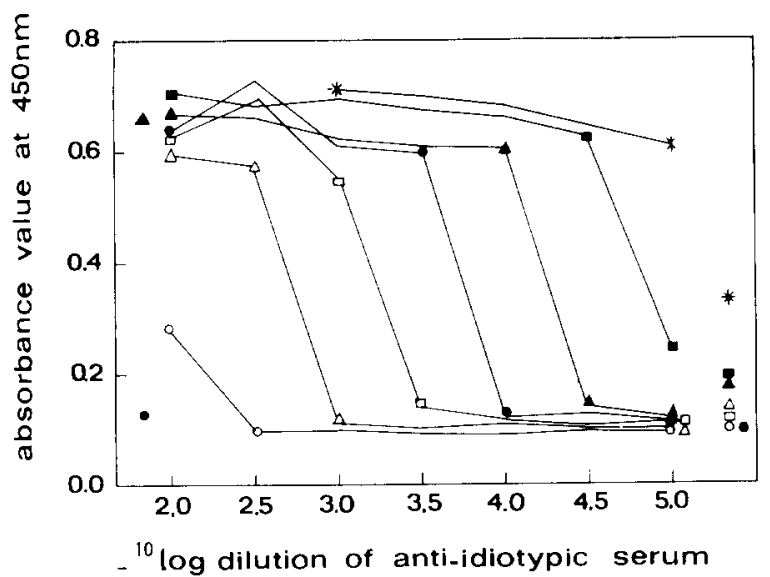

Fig. 2. Dependence of the titer of anti-idiotypic serum on the amount of idiotypic MA. Dilutions of MA UM 5.1 were mixed in 96-well plates with dilutions of NMS absorbed anti-idiotypic serum. After $1 \mathrm{~h}$ incubation at $37^{\circ} \mathrm{C} \mathrm{SFV}$ was added to each well followed by further incubation $(1 \mathrm{~h})$ at $37^{\circ} \mathrm{C}$. Then $\mathrm{L}$ cells were pipetted into the wells. After $6 \mathrm{~h}$ incubation at $37^{\circ} \mathrm{C}$ the EIA was performed with HRPO-labelled MA UM 1.4. Straight lines connect single absorbance values measured in the presence of a constant dilution of MA UM 5.1 and graded dilutions of anti-idiotypic serum. Symbols for $-{ }^{10} \mathrm{log}$ dilutions of MA UM 5.1 (continuous lines and single symbols to the right): $\bigcirc, 3.0 ; \Delta, 3.5 ; \square, 4.0 ; \bullet, 4.5 ; \Delta, 5.0 ; \mathbf{m}, 5.5$; and $*, 6.0$. The symbols to the right of the figure represent $a b-$ sorbance values measured with graded dilutions of MA UM 5.1 alone. Symbols left: $\bullet$, mean $(n=6)$ absorbance values measured against noninfected $\mathrm{L}$ cells; $\Delta$, mean $(n=6)$ absorbance value of virus control. cross-reactivity to a considerable degree, but they become highly specific after absorption with NMS. The titer of absorbed anti-idiotypic serum is clearly dependent on the dilution of the idiotypic MA used as shown in Fig. 2. Dependent on the dose of MA UM 5.1 the titer of anti-idiotypic serum varied from less than 100 to over 100000 .

With the NI-EIA anti-idiotypic antibodies could be also determined in mouse immune serum as demonstrated in the next experiment. Two step dilutions $(1 / 8-1 / 1024)$ of five individual immune sera against MA UM 5.1 were preincubated with a standard dilution of MA UM $5.1\left(-{ }^{10} \log\right.$ dilution: 4.5 ) before SFV and later $\mathrm{L}$ cells were added. After a multiplication time of $6 \mathrm{~h}$ at $37^{\circ} \mathrm{C}$ the EIA was performed. As shown in Table IV all mouse immune sera abrogated the neutralizing activity of MA UM 5.1 and NMS had no such effect.

\section{Discussion}

The present study shows that both rabbit and mouse anti-idiotypic immune sera inhibit the neutralizing capacities of SFV neutralizing MAs. Similar results were obtained by McClintock et al. (1986) with rabbit anti-idiotypic antibodies against Coxsackie $\mathrm{B}_{4}$ virus neutralizing MAs. With a cytopathic effect (CPE) inhibition test low anti-id titers $(<100)$ were measured, visually 3 days after infection. In another study Gheuens et al. (1981) have described that measles-specific MAs are inhibited in their neutralizing activity by mouse anti-idio- 
typic serum. They used a plaque reduction test with a duration of 6 days.

Our objective NI-EIA developed for titration of anti-idiotypic antibodies against SFV neutralizing MAs takes only $8 \mathrm{~h}$ to perform. The sensitivity of the anti-idiotypic test depends on the neutralization titer of the idiotypic MA used. A 1000-fold greater dilution of MA UM $5.1\left(10^{6}\right.$ to $\left.10^{3}\right)$ correlates with more than a 1000 -fold higher $\left(10^{5}\right.$ compared to $10^{2}$ ) titer of anti-idiotypic serum (Fig. 2). The high titers of anti-idiotypic sera against MA UM 5.1 measured with the NI-EIA compare well to those obtained with the solidphase EIA.

Rabbit anti-idiotypic serum against MA UM 5.1 (IgG2a), previously absorbed with NMS, does not cross-react with MA UM 1.4 (IgG2a) and vice versa in both the solid-phase EIA and the NI-EIA (Tables I and II). These results indicate a high specificity of both tests. In the NI-EIA anti-idiotypic antibodies are detected that abrogate the neutralizing capacity of neutralizing MAs. This result not necessarily signifies that all anti-idiotypic antibodies interfere with the function (i.e., neutralization) of the combining site. This problem must be approached with monoclonal anti-idiotypic antibodies to obtain an answer whether all anti-idiotypic antibodies are involved.

The NI-EIA might be useful for the detection of monoclonal anti-idiotypic antibodies. In the NI-EIA the binding of anti-idiotypic antibody is in fluid and both antibodies are not changed either by binding to a solid phase or conjugation to an enzyme.

In this paper we also demonstrate that homologous anti-idiotypic antibodies are induced if female BALB/c mice are intra/subcutaneously immunized with MA coupled to KLH and mixed with Quil A. Two injections 3 weeks apart are sufficient to induce immune sera which have specific titers over $1 / 1000$ in a conventional solid-phase EIA (Table II). In male BALB/c mice only low levels of anti-idiotypic antibodies are induced with the described immunization procedure (results not shown). The properties of the homologous anti-idiotypic antibodies are subject of further study.

In conclusion: the NI-EIA is a relevant method which detects anti-idiotypic antibodies interfering with the neutralizing capacity of MAs. The test is specific, objective, and highly sensitive with strongly neutralizing MAs.

\section{Acknowledgement}

This study was supported by the Institute for Molecular Biology and Medical Biotechnology, Utrecht, The Netherlands.

\section{References}

Boere, W.A.M., Harmsen, M., Vinjé, J., Benaissa-Trouw, B.J., Kraaijeveld, C.A. and Snippe, H. (1984) Identification of distinct antigenic determinants on Semliki Forest virus by using monoclonal antibodies with different antiviral activities. J. Virol. 52, 575-582.

Boere, W.A.M., Harmsen, M., Kraaijeveld, C.A. and Snippe, H. (1986) Antigenic differences between virulent and avirulent strains of Semliki Forest virus detected with monoclonal antibodies. Arch. Virol. 88, 105-112.

Burdette, S. and Schwartz, R.S. (1987) Idiotypes and idiotypic networks. New Engl. J. Med. 317, 219-224.

Ey, P.L., Prowse, S.J. and Jenkin, C.R. (1978) Isolation of pure IgG1, IgG2a and IgG2b immunoglobulins from mouse serum using protein A Sepharose. Immunochemistry 15, $429-436$.

Fazekas De St.Groth, S. and Scheidegger, D. (1980) Production of monoclonal antibodies: strategy and tactics. J. Immunol. Methods 35, 1-21.

Gheuens, J., McFarlin, D.E., Rammohar, K.W. and Bellini, W.J. (1981) Idiotypes and biological activity of murine monoclonal antibodies against the hemagglutinin of measles virus. Infect. Immun. 34, 200-207.

Kennedy, R.C. and Dreesman, G.R. (1985) Immunoglobulin idiotypes: analysis of viral antigen-antibody systems. Prog. Med. Virol. 31, 168-182.

Köhler, H., Muller, S. and Bona, C. (1985) Internal antigen and immune network. Proc. Soc. Exp. Biol. Med. 178, 189-195.

McClintock, P.R., Prabhakar, B.S. and Notkins, A.L. (1986) Anti-idiotypic antibodies to monoclonal antibodies that neutralize coxsackievirus $B_{4}$ do not recognize viral receptors. Virology $150,352-360$.

Nakane, P.K. and Kawaoi, A. (1974) Peroxidase-labeled antibody: a new method of conjugation. J. Histochem. Cytochem. 22, 1084-1091.

Uytdehaag, F.G.C.M. and Osterhaus, A.D.M.E. (1985) Induction of neutralizing antibody in mice against poliovirus type II with monoclonal anti-idiotypic antibody. J. Immunol. 134, 1225-1229.

Van Tiel, F.H., Boere, W.A.M., Harmsen, M., Benaissa-Trouw, B.J., Kraaijeveld, C.A. and Snippe, H. (1986) Rapid determination of neutralizing antibodies to Semliki Forest virus in serum by enzyme immunoassay in cell culture using virus specific monoclonal antibodies. J. Clin. Microbiol. 24, 665-669. 